\title{
A Review of the Relationship between Agency Cost and Corporate Investment Efficiency
}

\author{
Shan Li \\ School of Management, Jinan University, Guangzhou, China \\ Email: 13259743976@163.com
}

How to cite this paper: Li, S. (2020). A Review of the Relationship between Agency Cost and Corporate Investment Efficiency. American Journal of Industrial and Business Management, 10, 734-748.

https://doi.org/10.4236/ajibm.2020.104050

Received: March 13, 2020

Accepted: April 11, 2020

Published: April 14, 2020

Copyright $\odot 2020$ by author(s) and Scientific Research Publishing Inc. This work is licensed under the Creative Commons Attribution International License (CC BY 4.0).

http://creativecommons.org/licenses/by/4.0/

\begin{abstract}
Investment is the direct driving force for the survival and development of a corporate. Improving the efficiency of corporate investment is vital to the corporate value. And agency cost directly affects a series of business behaviors and results. This article reviews the agency costs, corporate investment efficiency, and the relationship between them, and studies how to improve corporate investment efficiency from the perspective of reducing agency costs.
\end{abstract}

\section{Keywords}

Agency Costs, Investment Efficiency, Internal Control, Principal-Agent Problem

\section{Introduction}

The investment is a driving source for value creation and growth of an enterprise. High-efficiency investment behavior is conducive to gaining market opportunities, increasing competitiveness, improving the efficiency of capital use. Therefore, making efficient investment is related to the survival and development of the enterprise. The research on corporate investment efficiency occupies an important position in the fields of economics, corporate governance research, corporate finance, policy formulation, and financial management. The inefficient investment mainly manifests itself in two forms: overinvestment and underinvestment, which are important factors hindering the long-term development of an enterprise. Therefore, how to effectively improve the investment efficiency and suppress the occurrence of inefficient investment behaviors of enterprises has become one of the core issues of enterprise management.

With the establishment of the modern enterprise system, the separation of the two powers of the enterprise has produced two types of agency conflicts, namely, 
agency conflicts between managers and shareholders under decentralized equity and agency conflicts between controlling shareholders and minority shareholders under equity concentration. The two types of agency conflicts generate agency costs, making the behavior of the manager as the actual agent of the enterprise may deviate from the goal of maximizing the value of the enterprise and make inefficient investment behaviors. In the case of decentralized equity, all shareholders have a free-rider behavior, resulting in shareholders being unable to effectively exercise their right to oversight, and the actual control of the company is in the hands of management. The purpose of operating costs is likely to reduce the level of their own business efforts, to maximize the personal benefits of investment activities rather than the shareholders' interests, resulting in inefficient investment behavior of the enterprise, such as excessive investment and expansion of non-productive consumption. In the case of concentration, the major shareholders actually have control of the enterprise and can effectively participate in the management of the enterprise to avoid the aforementioned free-riding behavior. In order to obtain control gains, this behavior will also cause the company to make inefficient capital investments. Enterprise investment may result in underinvestment due to agency problems or overinvestment due to agency costs (Jensen, 1986, 1993). Whether it is short-term behavior such as under-investment or over-investment, it will have an adverse effect on the long-term development of the enterprise, weaken the competitiveness of the enterprise, and lead to a decline in performance. Therefore, by studying the relationship between agency costs and corporate investment efficiency, exploring how to reduce agency costs and improve corporate investment efficiency has become a hot topic in corporate management research.

This article reviewed the literature on agency cost and investment efficiency from the following parts. First, the concept of agency cost and its affecting factors are reviewed. Second, this paper reviewed the concepts of investment efficiency, affecting factors, and the relationship between agency costs and investment efficiency. Finally, the conclusions, contributions and deficiencies of this article are further summarized.

\section{Review of Agency Cost Research}

\subsection{The Concept of Agency Costs}

Agency Costs are derived from the Agency Theory proposed by Jensen and Meckling (1976). They believe that due to the contractual arrangement between the internal owners and executives of the enterprise, the managers of the enterprise are not the full owners of the enterprise, and this separation of asset ownership from the right to use will lead to a principal-agent relationship between shareholders and managers. The agency cost is generated in the principal-agent relationship, which is the price paid for designing, supervising, and restricting a series of contracts of conflicts of interest between the principal and the agent, plus the residual loss of the cost exceeding the revenue when the contract is ex- 
ecuted. Jensen \& Meckling (1976) defined agency costs as the sum of the principal's supervisory expenses, the agent's guaranteed expenses, and residual losses based on a highly dispersed shareholding. The first is the cost of the client's supervision, that is, the cost incurred by the client to work hard for the client by supervising the agent. The second is the cost of the agent's guarantee, that is, the cost of the agent's guarantee that it will not harm the interests of the client, and the costs that the agent will compensate if the client's interests are harmed. The third is the residual loss, which is the loss of the client's benefit caused by the difference between the decision to maximize the client's interest and the agent's decision. It mainly includes the explicit loss such as on-the-job consumption and hidden loss such as lazy work.

Jensen and Meckling (1976) mainly distinguish two types of agency costs: one is the agency cost arising from conflicts of interest between shareholders and managers; the other is the agency cost arising from conflicts of interest between creditors and shareholders. In the modern enterprise system, ownership and management rights are separated. Because they are not or are not the owners of the enterprise, managers need to share the economic results achieved by hard work with shareholders, and they can take advantage of activities such as on-the-job consumption. Therefore, managers may take actions to seek their own interests and harm the interests of shareholders, thus incurring equity agency costs between shareholders and managers. The cash flow caused by debt and creditor supervision can restrain the manager's behavior to a certain extent, thereby alleviating the conflict of interest between shareholders and managers. However, since the creditors can only get a fixed share in the distribution of benefits, the shareholders can Full residual income can be obtained, so when the project is successful, shareholders will get most of the benefits, but creditors' returns are very limited; when the project fails, creditors will have to bear most of the losses, losing their loaned funds, and the shareholders bear Losses are limited. Therefore, this conflict of interest results in debt agency costs for shareholders and creditors.

Shleifer \& Vishny (1997) believed that the concentration of equity is commonly used to help investors recover funds, but at the same time there will be a redistribution of wealth between major shareholders and other shareholders, that is, the predation of major shareholders to the interests of small shareholders, therefore, the third type of principal-agent cost is incurred. La Porta et al. (1999) studied the sample companies in 27 high-income countries and selected $20 \%$ of the shares as the standard of corporate control. They found that $63.5 \%$ of large companies have controlling shareholders, so they propose that equity concentration is more common than equity dispersion. Based on this, it is proposed that in the companies with concentrated equity, in order to pursue the gains of control, the large shareholders and their agents who have substantial controlling power often do not make investment decisions in accordance with the principle of maximizing corporate value. Investment projects in the interests of small and medium shareholders, thus wantonly occupying the interests of small and me- 
dium shareholders, forming an agency conflict between the controlling shareholder and the small and medium shareholders, thus generating the agency costs between the large and small shareholders (Ang et al., 2000).

The current research focused on two different agency costs: one is the agency cost between shareholders and management of the enterprise proposed by Jensen and Meckling, which is also called the first type of agency cost. The other is the agency cost between the company's main controlling shareholder and other small and medium investors due to conflicts of interest, also known as the second type of agency cost.

\subsection{Factors Affecting Agency Costs}

1) Disclosure quality of corporate accounting information

The quality of corporate accounting information disclosure is an important restraining force for enterprises, which can improve the company's governance structure. The transparency of the information disclosure system can effectively alleviate the two major agency conflicts in the field of corporate governance. The transparency of accounting information can reduce the degree of information asymmetry between various stakeholders and reduce the possibility of insiders using information advantages for personal benefits. Based on the principal-agent theory, external investors and corporate contracts will constrain managers to maximize shareholder benefits, while transparency in accounting information is an important internal governance mechanism for investors to effectively monitor and exercise their legal rights. Listed companies can improve their accounting by Information transparency solves the company's internal governance issues, mitigates conflicts of interest, reduces adverse selection, and reduces agency costs (Lin \& Li, 1997). The transparency of accounting information is an important means to resolve information asymmetry under the separation of ownership and management rights. Studies by some scholars have shown that improving the transparency of accounting information can enable insiders to obtain less private information, and thus reduce the cost of obtaining information by external stakeholders (Filatotchev \& Nakajima, 2014). More importantly, through the improvement of information transparency, shareholders can understand the true operating status of the company, monitor the investment behavior of management, and establish a reasonable evaluation mechanism to reduce the risk of management deviation from shareholders' interests and wishes ( Du \& Zhou, 2009). Luo \& Zhu (2010) studied the impact of agency costs between shareholders as owners and managers as managers on the quality of corporate information disclosure, and argued that when the agency costs of a company are high, the shareholder's insufficient supervision requires shareholders to spend greater costs to monitor the behavior of management. Managers will be more inclined to make investment decisions that are not conducive to maximizing corporate value or maximizing shareholder rights, but are beneficial to maximizing their own interests. In order to circumvent the supervision of shareholders and external investors, management may conceal relevant information 
of the enterprise or reduce the information disclosed voluntarily. When agency costs are higher, managers may be more inclined to make decisions that are beneficial to their own interests but may harm shareholders' interests, and therefore tend to conceal information or reduce voluntary disclosure information.

2) Enterprise debt structure

Jensen (1986) believes that the conflict between the owner and management of a company is usually also affected by the size and cash flow of the company. Corporate debt can effectively reduce the cash flow that managers can spend, transfer some cash to creditors, increase the degree of supervision of corporate managers, and reduce agency costs. Zhang et al. (2008) also showed that the level of corporate debt is significantly positively related to the agency cost of the enterprise.

3) Enterprise's equity balance

The degree of ownership balance can also be called the degree of equity control, which is used to measure the strength of the controlling shareholder and other external shareholders. Kun \& Qin (2007) conducted an empirical test using Chinese listed companies as a sample and found that the balance of equity and the two types of equity agency costs were positively and negatively correlated, but failed to pass the significance test. Hao, Gong, and Sun (2009) research shows that there is no obvious correlation between agency costs and the shareholding ratio of the top five shareholders of the enterprise. Zhang, Yan, \& He (2008) found different conclusions. They found through empirical analysis that the shareholding ratio of the second to ten largest shareholders is negatively related to agency costs, and that the impact is better than that of state-owned enterprises.

4) Managers' salary gap

Management incentives include both explicit incentives based on monetary compensation contracts and implicit incentives in the form of reputation, replacement, and promotion (Zhang et al., 2013). Some scholars believe that an effective incentive mechanism can reduce agency costs and curb managers' excessive investment behavior. The internal salary gap of executives encourages managers to promote, coordinate the interests between shareholders and managers, externalize the private interests of managers, prompt managers to abandon investment projects with negative net present value, and curb their excessive investment behavior. Another view is that under the analysis framework of behavior theory, as the pay gap continues to expand, over-investment will increase. The excessive salary gap of the senior management team will reduce the satisfaction of low-paid managers, leading to negative work, deviation from corporate value creation goals, short-sighted work behavior, and the agency costs between shareholders and shareholders will continue to increase. Therefore, a moderate pay gap can reduce agency costs between shareholders and managers, and curb overinvestment. However, as the pay gap continues to increase, the inhibitory effect on overinvestment is reduced, which instead increases the agency cost and 
increases the overinvestment phenomenon.

5) Enterprise property right structure

The property right structure of an enterprise determines the nature of the enterprise. When the owner and the operator are united, the agency conflict between the two is relatively weak, and the objective function is the same. Private companies that are solely invested by individuals have the lowest degree of separation between remaining claim and ultimate control, and the lowest agency costs. When an investor has only one person concurrently serving as a manager, the agency costs are zero. The more managers are, the higher the agency cost will be. The nature of the property rights of an enterprise determines the principal-agent relationship of the enterprise, which results in significant differences in agency costs and agency efficiency. Among enterprises with different property rights, debts in state-owned enterprises have the worst restraint on excessive investment. Compared with private enterprises, state-owned enterprises have more complicated agency-agent relationships and higher agency costs, which make them lack of incentives and insufficient supervision (Amp \& Kangtao, 2013).

6) Internal control

Internal control can limit the abuse of managers' and controlling shareholders' residual control rights through a series of institutional arrangements, which reduces agency costs. Most studies on the effect of internal control on agency costs use data from listed companies to verify the inhibitory effect of internal control on agency costs through empirical research methods, that is, the quality of internal control is directly or indirectly negatively related to agency costs. Research believes that the increase in corporate information transparency can alleviate the asymmetry of information between the company's internal collective interests and between the company and external stakeholders, thereby effectively monitoring and restricting company management. This reduces the moral hazard problem for managers, which can reduce agency costs. Yang, Lin, and Wang (2009) found that the quality of internal control and external audit has a certain substitution effect. The implementation of the internal control system has a significant inhibitory effect on the agency costs between managers and shareholders, and between major shareholders and small and medium shareholders. Yang, Wang, and Cao (2010) divided agency costs into explicit agency costs and implicit agency costs, and proposed that the negative correlation between internal control quality and explicit agency costs was not significant, but positive correlation with implicit agency costs. Significantly, internal control played a more significant role in suppressing hidden agency costs.

\section{Review of Corporate Investment Efficiency Research}

\subsection{The Concept of Investment Efficiency}

Investment efficiency refers to the state of resource allocation formed by corporate investment and financing activities. Enterprise investment efficiency directly affects the performance of enterprises and the improvement of enterprise value. 
According to the viewpoint of modern enterprise investment theory, the key to judging the efficiency of an investment project is the net present value rule, that is, if a project with a negative net present value is invested or abandoned an investment project with a positive net present value. Such an investment is an inefficient investment, which reduces the investment efficiency of the enterprise and further damages the value of the enterprise. Underinvestment and overinvestment are two forms of inefficient investment. The greater the degree of underinvestment or overinvestment, the higher the degree of corporate investment alienation and the worse the investment efficiency. Underinvestment is the behavior of investment decision makers who abandon investment when they understand that the net present value of certain investment projects is positive and will bring certain returns to the enterprise. Overinvestment is the net present value of investment projects if the value is negative and it is likely to bring certain losses to the enterprise, it is still an investment behavior for its own benefit. The separation of ownership and management rights in modern enterprises has caused the problem of principal-agent and information asymmetry between the owner and the management, which has reduced the company's ability to allocate resources reasonably and effectively, resulting in a large number of inefficient investments.

\subsection{Factors Affecting Agency Costs}

The factors affecting the investment efficiency of enterprises can be divided into two aspects: macro and micro. The macroeconomic environment in which an enterprise is located is the basis of its development. The economic situation will affect the performance of the enterprise, and it will also have a significant impact on the investment behavior of the enterprise. For example, under the influence of the global financial crisis in 2008, the economic situation continued to decline, and many enterprises were limited by the severe economic environment due to factors such as shortage of funds and increased risk, which will tighten investment behavior and cause insufficient investment. In order to increase investment and revive market conditions, the country will introduce a series of loose monetary policies to stimulate investment and promote economic growth. If market capital is overheated, the country will need to tighten monetary policy, raise interest rates, and curb investment. Especially with the continuous deepening of global economic integration, the operating environment of enterprises has become more complicated. Due to the changes in the international macroeconomic situation, the investment behavior of enterprises has also changed. It is necessary to continuously adjust according to policies to improve investment efficiency.

In addition to the macro-influencing factors, in the existing research, scholars at home and abroad mainly examine the impact of agency cost research on corporate investment efficiency from the aspects of corporate debt ratio, internal cash flow, management background characteristics, and corporate property rights.

1) Enterprise debt ratio

The conflict of interest between creditors and shareholders may lead to ineffi- 
cient investment behaviors such as asset replacement and insufficient investment of listed companies. When debt financing costs are low, shareholders will tend to choose higher risk investment projects, or give up choosing lower risk projects, which will easily lead to excessive investment; when listed companies have more financial constraints due to information asymmetry. At this time, corporate creditors tend to increase the financing cost of the enterprise. At this time, the enterprise will abandon some investment projects, regardless of whether the investment's net present value is positive, resulting in insufficient investment. At the same time, considering the impact of the market value of the company on the manager's interests, for self-interest motivation, the manager is liable to make excessive investment behaviors, and corporate debt financing will reduce the free cash flow that the manager can spend due to its form, thereby inhibiting its excessive investment behavior optimizes investment decisions of enterprises. Jensen (1986) believes that by transferring a portion of the cash flow to creditors, the liability reduces the cash flow that the management can control, strengthens the supervision of the management, and is conducive to improving the investment efficiency of the enterprise. Hennessy (2010) found that if excessive debt problems arise due to high debt levels, managers will be forced to abandon profitable investment projects, especially long-term investment projects, resulting in underinvestment.

2) Internal cash flow

Due to the incompleteness and asymmetry of market information, credit rationing will affect banks to lend funds to enterprises, that is, banks do not accept whether interest rates are accepted by lenders as a criterion for lending, but are affected by risk factors (Stiglitz \& Weiss, 1981). At this time, the internal cash flow of the enterprise determines the investment level of the enterprise, and enterprises with sufficient internal funds will obtain a great market competitive advantage. The investment efficiency of a company will have a certain dependence on internal cash flow. Goergen \& Reneboog (2001) studied the relationship between investment and cash flow and found that the dependence of investment on cash flow will be affected by the ownership structure of the enterprise: that is, if the company's major shareholders are industrialists, they will tend to overinvest. For example, the research suggests that the problem of excessive investment caused by free cash flow in China's listed companies is significant. Murphy \& Conyon (2000) believe that the inefficient investment behavior caused by agency costs between shareholders and managers leads to a high correlation between corporate investment and cash flow.

3) Background characteristics of managers

Managerial background characteristics mainly refer to the demographic background characteristics of managers, including age, gender, educational background, education specialty, work experience and tenure, etc. (Hambrick \& Mason, 1984). Different background characteristics may affect managers' investment behavior decisions, and then affect corporate performance (Carlsson \& Karlsson, 1970). The “Top Management Team” (TMT), which was first pro- 
posed by Hambrick and Mason (1984), holds that the demographic characteristics (mainly including age, tenure, academic background, professional background, etc.) of the executive team of an enterprise Manager's behavior affects the investment activities of enterprises (Hambrick \& Mason, 1984). Jiang et al. (2009) used the "high-level echelon theory" to study the influence of background characteristics of management and chairman on excessive investment in enterprises. The results of the research show that the background characteristics of managers are closely related to the investment behavior of enterprises. At the same time, it was found that the overconfidence of managers has a positive correlation with abundant free cash flow. The rapid capital expansion caused by overconfidence will increase the possibility of companies falling into financial distress (Jiang et al., 2009).

4) Enterprise property rights

The impact of agency costs on corporate investment efficiency also shows significant differences due to the different nature of corporate property rights (Shleifer \& Vishny, 1994). Li (2007) believes that the structure of corporate governance is determined by the nature of property rights, so the nature of property rights will cause significant differences in agency costs and agency efficiency. Generally speaking, the agency costs of state-owned property companies are the highest, and the agency costs of individual property companies the lowest, mixed property enterprises are in the middle of the two.

\section{Agency Cost and Corporate Investment Efficiency}

The existence of agency cost may make the agent's behavior as the actual agent of the enterprise deviate from the goal of maximizing the value of the enterprise, which may lead to inefficient investment behavior of the enterprise. Zhang \& Zhang (2012) studied the impact of financing constraints and agency costs on corporate non-investment efficiency, and found that financing constraints are more likely to lead to underinvestment, and agency costs are more likely to lead to overinvestment. Huang (2011) also explored the path of earnings quality affecting investment efficiency from the perspective of agency problems, and proposed that the effective quality of earnings can reduce the cost of first-class agencies, thereby alleviating the problem of underinvestment in enterprises. As a result, the problem of excessive investment by enterprises has been suppressed. The first type of agency costs (the cost of agency conflicts between shareholders and managers) and the second type of agency costs (the costs of agency conflicts between major shareholders and small shareholders) and the agency between shareholders and creditors the research on cost and enterprise investment efficiency are sorted out separately.

\subsection{Agency Costs between Shareholders and Managers and Corporate Investment Efficiency}

Due to the principal-agent relationship between shareholders and managers, 
there is a conflict of interest between the two, and attitudes towards investment project risks are different. Corporate investment behavior often reflects the manager's goals, rather than the agency problem of maximizing shareholder value. As the actual manager of the enterprise, the manager's objective function deviates from the shareholders. Due to the asymmetric information and incomplete contract between the shareholders and the manager, the behavior of the manager is limited by the supervision of the shareholders, and self-interest behavior will occur.

Adverse selection caused by information asymmetry will result in financing constraints for enterprises. Financing constraints will result in the investment level of the enterprise is lower than the optimal investment, that is, the enterprise investment is relatively insufficient. Myers \& Majluf (1981) believe that due to adverse selection caused by information asymmetry, managers will be inefficient in transmitting the quality of existing assets and investment opportunities to the market, which directly leads to the possibility that good investment opportunities may be difficult to raise enough Funding forced managers to abandon investment opportunities with a positive NPV, leading to underinvestment. The interests of shareholders and managers will cause conflicts due to the separation of ownership and management rights, which will cause managers' decisions to deviate from the goal of maximizing shareholder value. Managers will use all funds for investment in order to maximize their own returns without considering investment projects Net present value situation leading to over-investment (Jensen \& Meckling, 1976). Jensen (1986) started from the assumption of the existence of asymmetric information between managers and shareholders, leading to the so-called overinvestment problem. Based on this, the free cash flow theory proposed that when the company's cash flow significantly exceeds its When it comes to profitable investment opportunities, dangerously high levels of debt increase the value of a company regardless of the threat of a financial crisis. When the mechanism used to align the interests of shareholders and managers may not be fully effective, Jensen believes that managers will have more funds than all the company's profitable investment projects, and managers may use free cash flow for private gain To carry out investment projects with a negative net present value in accordance with its own great interests, resulting in the inefficiency of corporate investment (Jensen, 1986).

Due to the existence of the first type of agency costs, managers' inefficient investment behavior will mainly manifest in the following three aspects: First, the empire building. Research by Jensen (1986) shows that: Generally, the faster the scale of the company expands, the more opportunities for managers to promote, so managers have an inherent motivation to expand the size of the company, rather than focusing on investing in items that maximize the value of the company. The second is investment myopia. Narayanan (1985) believes that an important criterion for managers to be selected by shareholders is still their previous operating performance. Therefore, for the purpose of building their own 
reputation, corporate managers tend to excessively pursue short-term benefits and tend to choose those who can make investment decisions. Projects that benefit in the short term, and abandon those long-term projects that are conducive to maximizing corporate value and maximizing shareholder benefits in the long run. The third is defensive motivation. For personal interests such as occupational safety, managers may make inefficient corporate investments. Baker et al. (2000) believe that managers tend to maintain projects that they have invested in the past but currently have poor operating performance, rather than liquidating or exiting them to avoid revealing past investment failures.

\subsection{Agency Costs between Controlling Shareholders and Small and Medium Shareholders and Corporate Investment Efficiency}

The control shareholder income from the participation of the major shareholders comes from two aspects, one is the equity income, and the other is the private benefit of the control, that is, the separation of the cash flow rights and the control rights due to the separation of the company's ownership and control rights. The economic income generated by its control is higher than the additional income of its shareholding. In the case of concentrated equity, large shareholders have the enthusiasm to supervise managers, which can reduce the agency costs between shareholders and managers, but at the same time, large shareholders will invade the interests of small and medium shareholders due to the pursuit of private benefits of control.

The agency conflict between major shareholders and small and medium shareholders may be manifested in the inefficient choice of investment projects and the inefficient choice of investment scale. Shleifer \& Vishny (1997) believe that when controlling shareholders control most of the company's decision-making rights, they may expand the controlling assets they own by increasing the company's capital investment, thereby forming private benefits of control that cannot be shared by small and medium shareholders. Claessens, Djankov, and Lang (2000) research finds that large shareholders usually obtain a large number of controlling capital accounts that exceed cash flow rights at the cost of small and medium shareholders' capital investment, using pyramid-shaped equity investment and resource expansion investment As a result, the main source of control shareholder's income from the formation of major shareholders was formed. Some argued that the second type of agency problem of conflicts of interest between large shareholders and small shareholders may cause the company to purchase the controlling shareholder's assets at a price higher than the market price, or invest in a negative net present value for shareholders Projects, triggering overinvestment. Wu \& Wang (2005) believes that the pursuit of private interest in control is the main factor that triggers excessive investment in the company, but moderate private interest in control can alleviate the underinvestment of controlling shareholders and help increase the value of the company. During the internal distribution of private interests of control, 
major shareholders will encroach on the interests of small and medium investors through self-interested behaviors such as distorted investments and inefficient allocation of funds between corporate departments; in the choice of capital investment and investment projects. The tendency for short-term self-interest projects rather than long-term $\mathrm{R} \& \mathrm{D}$ projects is widespread.

\subsection{Shareholder and Creditor Agency Costs and Corporate Investment Efficiency}

Based on the premise that the objective functions of shareholders and managers are consistent, Jensen \& Meckling (1976) believe that after borrowing debt, considering that limited liability of shareholders can help shareholders to obtain successful high-risk returns and reduce the burden of failed investment projects, the shareholders meeting Tend to choose high-risk investment projects and make excessive investment (Jensen \& Meckling, 1976). In addition, conflicts of interest are specifically manifested in the inherent motivation and moral hazard behavior of shareholders who have transferred the interests of creditors to their own hands after the company has signed a debt contract. Research by Hennessy (2010) shows that if excessive debt problems arise due to excessive debt levels, managers will be forced to abandon profitable investment projects, especially long-term investment projects, resulting in underinvestment.

\section{Conclusion}

Based on the perspective of the principal-agent relationship, this article reviews the literature on the study of corporate investment efficiency and finds that the three types of agency costs are closely related to corporate investment efficiency. Among them, the first type of agency cost is the agency cost between shareholder managers. The relationship with corporate investment efficiency is a hot research topic. How to improve the investment efficiency of enterprises by controlling the influencing factors of agency costs and reducing the agency costs is vital to the value creation and sustainable development of enterprises. By reviewing the above literatures, the current research on agency cost and investment efficiency has been clearly summarized, and it is convenient for us to conduct more in-depth research on the basis of learning from previous research ideas and methods.

Generally, in the research of agency costs and corporate investment, some literatures and theories have become classics in academic history, and the relationship between agency costs and investment efficiency has also achieved many very important research results. Western scholars mainly focus on the agency costs and corporate investment behavior under mature market economy conditions. Most of the studies in China have inherited western investment theories and research methods to explain China's investment and financing phenomenon. However, the heterogeneity of the development history of the East and the West and the social institutional environment have made existing investment theories have an adaptation problem in explaining the Chinese investment phe- 
nomenon, such as changes in government functions caused by changing external institutional environments, and actions between government and enterprises rules and relationships. This also means that the relationship between corporate investment behavior, internal governance mechanisms and external governance mechanisms has a great deal of complexity, which requires us to think and explore systematically as a whole, and research in this area still remains to be further developed. Therefore, future research in the Chinese context should focus on exploring how the external governance mechanism interacts with the internal governance of the enterprise in the context of China's unique economic, cultural, and institutional environment and the transition economy, and then how it affects corporate investment behavior and its economic consequences.

\section{Conflicts of Interest}

The author declares no conflicts of interest regarding the publication of this paper.

\section{References}

Amp, L. H., \& Kangtao, Y. (2013). Does Corporate Tax Avoidance Affect Investment Efficiency? Accounting Research, No. 6, 47-53.

Ang, J. S., Cole, R. A., \& Lin, J. W. (2000). Agency Costs and Ownership Structure. Journal of Finance, 55, 81-106. https://doi.org/10.1111/0022-1082.00201

Baker, M., Gompers, P., Hart, O. et al. (2000). Career Concerns and Staged Investment: Evidence from the Venture Capital Industry. Harvard Business Review.

Carlsson, G., \& Karlsson, K. (1970). Age, Cohorts and the Generation of Generations. American Sociological Review, 35, 710. https://doi.org/10.2307/2093946

Claessens, S., Djankov, S., \& Lang, L. H. P. (2000). Separation of Ownership from Control of East Asian Firms. Journal of Financial Economics, 58, 81-112. https://doi.org/10.1016/S0304-405X(00)00067-2

Du, X. Q., \& Zhou, Z. J. (2009). Empirical Research on the Quality of Information Disclosure and Agency Costs: Empirical Evidence Based on Information Disclosure Evaluation of Shenzhen Stock Exchange. Business Economics and Management, No. 12, 78-82.

Filatotchev, I., \& Nakajima, C. (2014). Corporate Governance, Responsible Managerial Behavior, and Corporate Social Responsibility: Organizational Efficiency versus Organizational Legitimacy? The Academy of Management Perspectives, 28, 289-306. https://doi.org/10.5465/amp.2014.0014

Goergen, M., \& Renneboog, L. (2001). Investment Policy, Internal Financing and Ownership Concentration in the UK. Journal of Corporate Finance, 7, 257-284. https://doi.org/10.1016/S0929-1199(01)00022-0

Hambrick, D. C., \& Mason, P. A. (1984). Upper Echelons. Automatic Control \& Computer Sciences, 41, 39-43.

Hao, C., Gong, Y. J., \& Sun, L. X. (2009). An Empirical Study of the Impact of Governance Elements on Agency Cost: Data from Hu \& Shen Stock Markets of 2000-2007 in China. Soft Science, No. 10, 123-127.

Hennessy, C. A. (2010). Tobin's Q, Debt Overhang, and Investment. Journal of Finance, 59, 1717-1742. https://doi.org/10.1111/j.1540-6261.2004.00677.x 
Huang, X. N. (2011). The Path of Earnings Quality's Influence over Capital Allocation Efficiency: Based on Double Agency Relationship. Theory \& Practice of Finance \& Economics, 32, 62-68.

Jensen, M. (1986). Agency Costs of Free Cash Flow, Corporate Finance as Antitakeover Mechanisms: The Recent Evidence. Journal of Financial Economics, 20, 129-152.

Jensen, M. C. (1993). The Modern Industrial Revolution, Exit, and the Failure of Internal Control Systems. Journal of Finance, 48, 831-880. https://doi.org/10.1111/j.1540-6261.1993.tb04022.x

Jensen, M., \& Meckling, W. (1976). Theory of the Firm: Managerial Behavior, Agency Cost and Ownership Structure. Journal of Financial Economics, 3, 305-360. https://doi.org/10.1016/0304-405X(76)90026-X

Jiang, F. X., Zhang, M., Lu, Z. F., \& Chen, C. (2009). Managerial Overconfidence, Firm Expansion and Financial Distress. Economic Research Journal, No. 1, 131-143.

Kun, X., \& Qin, B. (2007). Study on Governmental Effect of Liabilities of Chinese Public Company. Economic Problems, No. 3, 113-115.

La Porta, R., Lopez-de-Silanes, F., \& Shleifer, A. (1999). Corporate Ownership around the World. Journal of Finance, 54, 471-517. https://doi.org/10.1111/0022-1082.00115

Li, S. X. (2007). Property Rights, Agency Costs and Agency Efficiency. Economics Research, $8,165-176$.

Lin, Y. F., \& Li, Z. (1997). The Connotation of Modern Enterprise System and the Reform Direction of State-Owned Enterprises . Economics Research, No. 3, 3-10.

Luo, W., \& Zhu, C. (2010). Agency Costs and Corporate Voluntary Disclosure. Economic Research Journal, No. 10, 143-155.

Murphy, K. J., \& Conyon, M. J. (2000). The Prince and the Pauper: CEO Pay in the US and UK. New York: Social Science Electronic Publishing.

Myers, S. C., \& Majluf, N. S. (1981). Stock Issues and Investment Policy When Firms Have Information That Investors Do Not Have. Social Science Electronic Publishing. https://doi.org/10.3386/w0884

Narayanan, M. P. (1985). Managerial Incentives for Short-Term Results. Journal of Finance, 40, 1469-1484. https://doi.org/10.1111/j.1540-6261.1985.tb02395.x

Shleifer, A., \& Vishny, R. W. (1994). The Politics of Market Socialism. Journal of Economic Perspectives, 8, 165-176. https://doi.org/10.1257/jep.8.2.165

Shleifer, A., \& Vishny, R. W. (1997). The Proper Scope of Government: Theory and an Application to Prisons. Quarterly Journal of Economics, 112, 1127-1161. https://doi.org/10.1162/003355300555448

Stiglitz, J. E., \& Weiss, A. (1981). Credit Rationing in Markets with Imperfect Information. American Economic Review, 71, 393-410.

Wu, X., \& Wang, Z. (2005). Equity Financing in a Myers-Majluf Framework with Private Benefits of Control. Journal of Corporate Finance, 11, 915-945. https://doi.org/10.1016/j.jcorpfin.2004.04.001

Yang, D. M., Lin, B., \& Wang, Y. C. (2009). Internal Control, Audit Quality and Large Shareholder Tunneling. Auditing Research, No. 5, 74-81.

Yang, Y. F., Wang, H. X., \& Cao, Q. (2010). The Correlation Study on Internal Control Information Disclosure Quality and Agency Cost-An Empirical Research Based on the Listed Companies of Shanghai Stock Exchange in 2007. Auditing Research, No. 1, $82-88$.

Zhang, Z. G., Liu, Y. W., \& Qi, X. L. (2013) Research on Management Background Cha- 
racteristics, Promotion Incentive and Over-Investment. Nankai Business Review, No. $4,32-42$.

Zhang, Z. G., Yan, B. Q., \& He, W. F. (2008). Capital Structure and Agency Costs: The Empirical Evidence from State-Controlling Listed Companies and Private Listed Companies in China. Nankai Business Review, 34, 39-47.

Zhang, Z. Y., \& Zhang, Z. D. (2012). The Influence of Financial Constraint and Agency Cost on Investment Inefficiency of Listed Firms: An Empirical Measurement Based on Two-Tier Stochastic Frontier Model. Journal of Industrial Engineering and Engineering Management, 26, 119-126. 